\title{
International reconciliation on the Internet? Ontological security, attribution and the construction of war memory narratives in Wikipedia
}

International Relations

(C) The Author(s) 2019

(c) (i) \&

Article reuse guidelines: sagepub.com/journals-permissions DOI: 10.1 | 177/0047| | 7819864410 journals.sagepub.com/home/ire

@SAGE

\section{Karl Gustafsson}

Stockholm University; Swedish Institute of International Affairs

\begin{abstract}
This article explores the Internet's often touted potential for facilitating reconciliation. It conceptualises Wikipedia as a site for collective memory construction and analyses the Chineseand Japanese-language entries on the bilaterally contentious Second Sino-Japanese War. It addresses the question of how to make sense of the construction of these online collective memory narratives theoretically. Both historical determinism and instrumentalism - two influential theoretical approaches to collective memory and reconciliation - have great difficulties in fully accounting for this case. Instead, it is argued that ontological security theory is better equipped for understanding collective memory construction in Wikipedia. It is suggested that ontological security seeking can impede efforts for reconciliation even when, as in Wikipedia, there exist norms seeking to promote more neutral narratives. It is argued that a subtle bias in favour of the in-group and against the out-group functions as a mechanism for ontological security management that protects a positive self-identity.
\end{abstract}

\section{Keywords}

attribution theory, collective memory, Internet, narrative, ontological security, reconciliation

\section{Introduction}

Numerous international disputes exist over how to remember past events. In addition, traditional conflicts over territory and resources are often exacerbated by divergent collective memories. Against this background, International Relations (IR) research has

\section{Corresponding author:}

Karl Gustafsson, Swedish Institute of International Affairs, Box 27035, 1025 I Stockholm, Sweden.

Email: karl.gustafsson@ui.se 
become increasingly interested in how collective memory matters in international politics. Such scholarship has explored, for example, the role of trauma in international politics $^{1}$ and how collective memory influences the security policy. ${ }^{2}$ The key issues being debated concern how collective memory influences interstate relations and how to achieve reconciliation between former enemies. ${ }^{3}$ The fact that the Internet has increasingly come to pervade social life raises questions about how it might affect the possibilities for reconciliation. Some argue that the Internet has the potential to facilitate increased international understanding in general. ${ }^{4}$ In addition, research in memory studies has suggested that the Internet could become an arena for the construction and promotion of more nuanced collective memory narratives without government interference. ${ }^{5}$ These suggestions notwithstanding, thus far, scant attention has been paid to how the Internet might influence reconciliation. This article addresses the conciliatory potential of the Internet through an analysis of narratives about the bilaterally contentious Second SinoJapanese War that took place during the 1930 s and 1940s. ${ }^{6}$ The analysis compares those narratives appearing in prominent Chinese and Japanese museum exhibitions with those constructed in the Chinese- and Japanese-language versions of Wikipedia. The article thus seeks to address the question of whether the online narratives are more conciliatory than the offline ones. In addition, it asks how we can make sense of these online collective memory narratives theoretically.

The article's focus on Wikipedia is grounded in insights from memory studies that conceptualise Wikipedia as a site for collective memory construction. ${ }^{7}$ As such, the article offers insights into the Internet's conciliatory potential. Wikipedia's guiding principle of striving to construct accounts based on a neutral point of view echoes what historical determinism - arguably the most influential theoretical approach to collective memory and reconciliation - suggests should facilitate reconciliation. Historical determinism assumes that even though political actors may seek to construct collective memory in accordance with their preferences, such accounts are difficult to sustain over time because sooner or later the narratives will be confronted with historical facts. Historical determinism has been extremely influential in research on reconciliation and transitional justice and in the practical measures - such as truth-seeking initiatives - that such research recommends. If Wikipedia functions according to its principles, it should be expected to facilitate more conciliatory narratives than those typically found in offline memory sites. It can thus be regarded as a favourable, indeed a most likely, ${ }^{8}$ setting both for the construction of more conciliatory memory narratives and for historical determinism.

By contrast, instrumentalism - another major school in the study of collective memory - holds that political elites construct collective memory to further their present and future interests. For instrumentalism, reconciliation is likely to occur if, but only if, it is in the interests of the elites that control the construction of collective memory. Instrumentalist approaches would expect narratives in Wikipedia to more or less reflect those that dominate in the offline sphere.

This article argues that the ontological security theory is better equipped for making sense of collective memory as constructed in Wikipedia. IR research on ontological security has suggested that, instead of adopting measures that could facilitate reconciliation, many states are more concerned with seeking ontological security by securitising memory. ${ }^{9}$ By contrast, through its analysis of Wikipedia, and by incorporating insights 
from the social psychological attribution theory, this article suggests that ontological security seeking can impede efforts for reconciliation even when there are norms seeking to promote more neutral narratives and an apparent willingness to narrate the past in less self-serving ways. It is argued that bias in favour of the in-group and against the out-group functions as a mechanism for ontological security management that protects positive in-group self-identity. This mechanism does not necessarily involve the outright denial of the negative acts of those understood as belonging to the in-group ${ }^{10}$ but a subtler downplaying of such acts. This alternative theoretical approach contributes to both research on reconciliation and ontological security.

The next section outlines how Wikipedia can be conceptualised as a collective memory site ${ }^{11}$ in general and more specifically as a space for reconciliation. The section that follows examines in greater detail the major approaches to collective memory and reconciliation and elaborates on the article's theoretical argument. Narrative analysis is then used to analyse and compare accounts of the war between China and Japan. The conclusion discusses the implications of the article's findings for theories of collective memory in IR, as well as for reconciliation.

\section{Collective memory and reconciliation on the Internet}

The existence of large numbers of international disputes over how to remember past events, and the fact that traditional conflicts over territory and resources are often exacerbated by divergent collective memories, has increased interest among IR scholars in collective memory. However, IR research has so far paid scant attention to how the Internet influences the politics of collective memory and reconciliation. This is despite the fact that the Internet has permeated all aspects of social life, that people increasingly get their information about both current and past events from the Internet and that social media has opened up greater possibilities for online knowledge production by ordinary people. $^{12}$

Reconciliation can be defined as "the process of moving toward a relatively cooperative and amicable relationship, typically established after a rupture in relations involving extreme injury to one or more sides in the relationship' ${ }^{13}$ Most approaches to reconciliation agree on this broad definition, even though some speak of 'thin' and 'thick' or 'shallow' and 'deep' reconciliation, where the former refers to 'simple coexistence' and the latter to 'forgiveness' or a 'shared comprehensive vision'. ${ }^{14}$ References to the importance of a 'shared comprehensive vision' suggest that reconciliation can be achieved by making collective memory compatible. ${ }^{15}$

Today, the narration of past events is not so confined to the offline sphere as was once the case. Moreover, such narratives are no longer merely consumed but instead increasingly constructed and negotiated online by ordinary people. Scholars believe that the Internet is able to facilitate the creation of a transnational public sphere for dialogue between people in different societies, ${ }^{16}$ thereby potentially contributing to increased international understanding. ${ }^{17}$ For example, Frances Cairncross has argued that 'people will communicate more freely and learn more about the aspirations of human beings in other parts of the globe', something which will 'increase understanding, foster tolerance, and ultimately promote worldwide peace'.${ }^{18}$ Although such arguments can seem overly 
optimistic, ${ }^{19}$ they nonetheless indicate that the Internet could facilitate the construction of different and possibly more conciliatory memory narratives than the offline sphere, something that is echoed in scholarship on Internet-based collective memory. ${ }^{20}$

Research on online collective memory has conceptualised Wikipedia as a memory site, ${ }^{21}$ by connecting Maurice Halbwachs' concept of collective memory, ${ }^{22}$ Jan Assmann's distinction between communicative and cultural memory, ${ }^{23}$ Pierre Nora's notion of memory sites ${ }^{24}$ and Jan Vansina's 'floating gap' ${ }^{25}$ Halbwachs argued that humans remember their pasts as members of groups that construct memory collectively by means of a selective communicative social process through which 'the past is not preserved but is reconstructed on the basis of the present'. ${ }^{26}$ Assmann divided such collective memory into communicative memory and cultural memory. The former is based on everyday communication between group members and therefore has a limited time frame of about 80 years (three interacting generations). The latter is 'exteriorised, objectified, and stored away in symbolic forms', ${ }^{27}$ such as 'monuments, museums, libraries, archives, and other mnemonic institutions', making it more 'formalised and stabilised' ${ }^{28}$ Vansina suggested that there is a gap between the collective memory of the relatively recent past communicated from generation-to-generation and that of the remote past. ${ }^{29}$ While Vansina was concerned with oral societies, Assmann argued that the floating gap concept has relevance for understanding the difference between communicative and cultural memory more generally, since "even in literate societies living memory goes no further back than eighty years after which, separated by the floating gap, come, instead of myths of origin, the dates from schoolbooks and monuments'. ${ }^{30}$ Nora conceptualised memory places as material or nonmaterial symbolic places that help collectives, national or otherwise, remember the past, often by providing some archival function..$^{31}$ Bringing together these theoretical building blocks, Pentzold conceptualised Wikipedia as a global memory place that connects cultural and communicative memory, its built-in functions making possible both archiving and communication with multiple dialogue partners and thereby overcoming the floating gap. ${ }^{32}$ There are many websites that have commemorative purposes, for example, online museums and archives, but most of these are edited by only one or a couple of individuals, typically those who launched the site to begin with. Wikipedia, by contrast, can be edited by anyone and its entries are jointly constructed by large numbers of people. Memory as constructed in Wikipedia is therefore collective rather than individual. ${ }^{33}$

In addition to being constructed by collectives, Wikipedia is also read by large groups of people. Search engine algorithms function so that a small number of sites, one of which is Wikipedia, receive a huge share of all Internet traffic. ${ }^{34}$ Many sites consequently get 'lost on the web ... partly because they tend to get a low search engine listing' ${ }^{35}$ and also because users do not typically look beyond the first 10 search results. ${ }^{36}$ This means that much of what is posted online, rather than belonging to collective memory, is backgrounded to such an extent that it is virtually consigned to oblivion. Consequently, much is 'stored but not remembered' on the Internet ${ }^{37}$ and a few websites dominate the online production of knowledge, including the production of narratives about the past. Wikipedia typically appears at the top, or near the top, of web searches. ${ }^{38}$ It is the world's fifth most visited website. ${ }^{39}$ Many users consequently get their information about historical events from Wikipedia. In fact, it is 'increasingly used as the first, and sometimes the only, stop for online encyclopaedic information'. ${ }^{40}$ 
Previous research has found that governments and other elite actors often hinder rather than contribute to reconciliation by, for example, promoting 'pernicious myths' ${ }^{41}$ It has thus been argued that bilateral initiatives trying to bring reconciliation, and discussions of how history is narrated, might be more successful if governments stay out of them. ${ }^{42}$ The fact that Wikipedia is known as the 'free encyclopaedia that anyone can edit' highlights its potential for facilitating the construction of alternative narratives without government interference. While earlier technologies of memory such as museums have tended to prioritise official narratives about the past, in Wikipedia ordinary people not only consume, but also construct and negotiate, knowledge about current and past events, thereby creating an evolving online collective memory narrative. ${ }^{43}$

In addition to reducing the probability of state interference, Wikipedia's principles also provide an important reason why it might be expected to facilitate the construction of more conciliatory narratives. Wikipedia entries are supposed to seek to produce knowledge from a 'neutral point of view', meaning that entries should represent 'fairly, proportionately, and, as far as possible, without editorial bias, all of the significant views that have been published by reliable sources on a topic'. ${ }^{44}$ With time, as they are edited by a large number of contributors, the quality of Wikipedia articles is therefore expected to increase and articles are supposed to become more neutral and accurate. As Wikipedia founder Jimmy Wales put it in 2010: 'One person writes something, somebody improves it a little, and it keeps getting better, over time. If you find it useful today, imagine how much we can achieve together in 5, 10, 20 years' ${ }^{45}$ The idea is that consensus concerning recognised knowledge will be achieved. ${ }^{46}$ In general, then, the more an entry has been edited, the more neutral and reliable it should be. Wikipedia can thus be regarded as a most likely setting for the construction of more conciliatory memory narratives. ${ }^{47}$ As elaborated below, the similarities between Wikipedia's principles and the historical determinist school in the study of collective memory also suggest that Wikipedia is useful for evaluating historical determinism's propositions.

Although different language versions of Wikipedia can be viewed as reflecting certain cultures or language communities, ${ }^{48}$ because of the existence of the neutral point-of-view principle, one might still expect entries in different languages to become increasingly similar over time and national biases to be overcome. At the very least, one should expect Wikipedia articles in different languages, especially those that have existed for a relatively long time and been edited many times, to be considerably more neutral and similar than different language versions of narratives found in traditional memory places such as history textbooks and museum exhibitions. The Chinese- and Japanese-language versions of the entries on the Second Sino-Japanese War have both been edited a very large number of times ${ }^{49}$ If Wikipedia functions according to its principles, one would therefore expect these narratives to have become relatively neutral and similar.

\section{Collective memory and reconciliation in International Relations}

Wikipedia provides a setting that allows researchers to explore the extent to which the Internet facilitates the construction of more conciliatory narratives about past events. As such, it can be understood as a barometer that measures the position of a community on 
collective memory of particular episodes. In addition, to the extent that leaders need to consider the narratives that are predominant within their societies, such narratives could either facilitate or constrain conciliatory government policies. Furthermore, exploring the narratives negotiated within two language communities about a controversial bilateral issue provides insights concerning the degree to which those communities are open to reconciliation. Most importantly for the purposes of this article, as a site for reconciliation, Wikipedia, as shown below, challenges the key approaches to collective memory in IR. The following section describes the major schools in the study of collective memory and reconciliation in general and specifically in relation to the Internet.

\section{Historical determinism}

Among the theoretical approaches to collective memory, historical determinism might be the most influential. It has had a tremendous impact on research on collective memory and reconciliation, particularly on what could be labelled as the transitional justice paradigm. It also permeates numerous post-conflict political initiatives centring on truth-seeking.

As the name suggests, historical determinism basically assumes that history itself what 'actually happened' in the past - determines collective memory. In other words, collective memory reflects 'historical facts'. This is not to say that historical determinism denies the possibility that attempts might be made by governments and influential elites to shape collective memory in accordance with their interests and visions. Some approaches to historical determinism concede that leaders and other powerful actors seek to manipulate collective memory and that, at times, they can be successful. However, they nonetheless argue that there will be resistance, for example, by civil society groups, to such instrumentalist efforts. Any attempts to distort narratives about the past will eventually be unsuccessful, because they will be confronted with the facts. Facts are seen as likely to strike back and undermine efforts at manipulation. Those who have experienced past events and episodes, and those who have heard about such experiences, will challenge the distorted accounts. This means that historical determinists might expect the collective memory of a particular episode or event to initially be based on the articulations of elite actors. Various domestic and international forces might then react to that account and confront it with historical facts, leading to modifications. As time passes, experiences and facts originally excluded are expected to be incorporated into the narrative. At the end of the day, the truth is expected to prevail..$^{50}$

Historical determinism implies that reconciliation can be achieved through a reconstruction of collective memory narratives that takes into account historical facts and the experiences of both the sides. Transitional justice initiatives such as truth-seeking and truth commissions, tribunals that hold perpetrators responsible, reparations to victims and so on, are linked to historical determinist ideas. The various initiatives that comprise transitional justice are meant to come up with evidence and indisputable facts about what transpired during conflicts that occurred in the past. On the basis of such initiatives, former enemies, both victims and perpetrators, are supposed to be able to more or less agree on how to remember the past conflict, or at least to recognise and sympathise with each others' experiences. Approaches that draw on historical determinism thus emphasise the necessity of squarely facing historical facts. ${ }^{51}$ 
In its focus on facts, historical determinism is based on a positivist and rationalist epistemology. It supposes that it is possible to construct accounts about past events and episodes without being influenced to a very large extent by one's own personal background. ${ }^{52}$ Initiatives where historians collaborate to write joint history textbooks are based on the historical determinist logic. Through such initiatives, historians from different countries come together to co-author textbooks that either seek to come up with a common narrative about a conflict that occurred in the past or to present the perspectives or experiences of both the sides. ${ }^{53}$ The role of historical evidence and facts in such endeavours is clearly similar to historical determinism. As argued by Ronald Grigor Suny:

reality has a nasty habit of biting back. When usable pasts and preferred realities are being proliferated, historians can take some comfort in the thought that dangers lurk when intellectual constructs stray too far from careful and accurate readings of the world. ${ }^{54}$

Wikipedia's approach to memory construction, as captured in its key principles, is closely aligned with historical determinism. Facts are expected to win over instrumentalist manipulation. Anyone can edit Wikipedia and the idea is that over time editing should lead to higher quality and more neutral and truthful accounts. In other words, even though there might be vandalism and even though some edits might reflect political interests and instrumentalist manipulation, over time, accounts should be expected to become more factual. Due to the way it has been designed and the norms it promotes, Wikipedia should favour historical determinism rather than instrumentalism. We should expect it to be more likely for Wikipedia accounts to be in line with historical determinism than instrumentalism, or some other theory.

\section{Instrumentalism}

The second major theoretical school in the study of collective memory, instrumentalism, holds that political elites construct collective memory to further their present and future interests, rather than to conform with historical facts. Powerful leaders, in particular, are seen as being in a position to construct and promote their preferred narratives about past events. In other words, collective memory is at the mercy of rational elites who not only seek to promote their interests but are also largely able to do so. A key issue for instrumentalists concerns which interests control the construction of collective memory. Because the state has resources that typically cannot be matched by other societal actors, the interests of the state or its leaders are most likely to construct a collective memory master narrative which is regarded as commonsensical by most of society. Other narratives might still exist, but they are likely to be marginalised or considered beyond the pale. At the same time, the more pluralistic societies are, the more difficult it becomes for the state to control collective memory. Instead, different memory narratives that support radically different political programmes might be pitted against each other. Instrumentalists do not deny the existence of facts or that certain events actually occurred. Instead, the key difference between historical determinism and instrumentalism is that while historical determinists see leaders as highly constrained by facts, instrumentalists believe that 
elites can more easily mould collective memory. For instrumentalists, reconciliation might therefore take place if it is in the interests of the elites in control of collective memory. However, if they are not in line with influential interests, it is unlikely that conciliatory narratives will come to dominate in society. ${ }^{55}$

Instrumentalist approaches, even the ones that are more open to the possibility of greater pluralism, would expect collective memory narratives in Wikipedia to be more or less in line with those that dominate in the offline sphere.

This article argues that both historical determinism and instrumentalism are insufficient for fully understanding the construction of collective memory narratives in Wikipedia. Instrumentalism appears to ascribe too much power to elites and to rational calculation. By contrast, historical determinism, even though it permeates Wikipedia's principles and most of its editors probably seek to abide by those principles, is arguably too optimistic about the possibility of constructing historical accounts without being influenced by one's background. In other words, these rationalist approaches arguably fail to appreciate the impact of identity-related needs on collective memory construction.

\section{An alternative approach: ontological security and attribution}

This article argues that the ontological security theory can provide a better understanding of collective memory construction in Wikipedia. To be ontologically secure means to have a secure sense of self and identity. It means being able to sustain one's biographical narrative through time. ${ }^{56}$ In IR, the ontological security theory typically assumes that not only individuals, but also states, have a fundamental need for not only physical security but also ontological security. IR research on ontological security has explored various ways in which states engage in ontological security seeking and manage threats to their ontological security. For example, states seek ontological security by routinising relationships with significant others, by avoiding actions that are incongruent with one's identity and by securitising identity. ${ }^{57}$ More specifically, it has been argued that states seek ontological security by securitising collective memory. Ontological security can thus be sought through various collective memory-related means: through denial of war crimes committed in the past, by criminalising some ways of narrating the past, and by removing monuments and references to certain events from history textbooks and museum exhibitions. ${ }^{58}$ These studies all indicate that ontological security seeking can impede efforts for reconciliation. The reason for this is that instead of reflexively adopting measures that could facilitate reconciliation, many states are more concerned with seeking ontological security by securitising memory.

This article, by contrast, argues that ontological security seeking can impede efforts for reconciliation even under circumstances that favour the construction of conciliatory narratives such as the existence of norms seeking to promote more neutral narratives. Even when a willingness to narrate the past in less self-serving ways appears to exist, bias in favour of the in-group and against the out-group functions as a mechanism for ontological security management. This kind of ontological security management does not involve the outright securitisation of memory or the denial of war crimes perpetrated by those understood as belonging to the in-group, but rather a subtler and possibly unconscious downplaying of such acts. 
Social psychological research on attribution suggests that group members tend to express bias in favour of those belonging to the group with which they themselves identify. ${ }^{59}$ One study that looked at evaluations and explanations of harmful behaviour, for example, demonstrated that, 'Out-group actors were perceived as more aggressive and intentional in their actions than in-group actors'. ${ }^{60}$ Such group-serving biases, which downplay the negative behaviour of in-group members and the positive behaviour of out-group members while emphasising the negative behaviour of out-group members and the positive behaviour of in-group members, are sometimes explained in the social psychology literature through reference to the need to maintain a positive in-group identity, echoing the ontological security literature. The positive behaviour of members of the in-group and the negative behaviour of members of the out-group tend to be attributed to their internal traits. In contrast, the negative behaviour of those belonging to the in-group and the positive behaviour of those who belong to the out-group are typically explained through reference to external factors such as the context within which events occurred. ${ }^{61}$ The main advantage of this approach is that it is able to account for bias in collective memory narratives even under conditions that should be favourable to the construction of more conciliatory accounts. It emphasises the role of psychological mechanisms that downplay 'our' bad actions and 'their' good actions while foregrounding our good actions and their bad actions. As shown below, it appears that in the case analysed in this article, even though attempts are made to construct unbiased accounts, such a mechanism is still in play. Overly negative portrayals of the group to which one believes one belongs might threaten one's ontological security. It is therefore possible that negative portrayals are downplayed, perhaps unconsciously.

In developing this mechanism for ontological security management, this article has drawn on insights from the social psychological attribution theory. While the ontological security theory and attribution theory have their roots in different strands of psychology, the attribution theory has a relatively specific and limited focus while the ontological security theory has a broader range. It is thus possible to incorporate attribution into the ontological security theory as one among several mechanisms for ontological security management while maintaining theoretical coherence. The mechanism is also in line with recent research on ontological security, according to which the key to maintaining ontological security is to uphold a positive view of the self. ${ }^{62}$ The mechanism exemplifies one way in which a positive view of the self is sustained.

\section{Analysing narratives}

The degree to which collective memory narratives are conciliatory can be explored through a two-step process. First, do the two sides remember completely different events and episodes? Second, are the episodes narrated in radically different or compatible ways? ${ }^{63}$ Narratives are 'stories [that] tell about things that have happened or are happening to people, animals, aliens from outer space, insects - whatever'. They contain a 'sequence of events, which means that narratives take place within or over . . . some kind of time period'. ${ }^{64}$ The ways in which sequences and events are linked together create causal relations, because one occurrence is followed by and often presented as causing another. Arranging occurrences differently usually alters the meaning that the narrative 
constructs. Furthermore, the mere fact that a narrative contains an ending that excludes subsequent occurrences influences its meaning. ${ }^{65}$

Narratives have been theorised as consisting of five elements that correspond to different questions: 'what was done (act), when or where it was done (scene), who did it (agent), how he $\left[\right.$ sic] did it (agency), and why (purpose)' ${ }^{66}$ In addition, narratives typically conclude by presenting lessons for the future or suggestions about what policies to adopt. ${ }^{67}$ Analysing the scene involves exploring when and where the action takes place. When does the story begin and when does it end? How is the setting in which the protagonists find themselves depicted and what options are open to them? For example, if the setting is depicted as being a war of all against all, the protagonists are likely to be depicted as being forced to act accordingly, which will increase the likelihood that their actions appear understandable. The setting can thus influence the purpose, or why someone does something. The remaining questions relate to the depiction of the protagonists in a narrative: whether agency and thereby responsibility are obfuscated, and whether the protagonists are positively or negatively described. This framework for narrative analysis makes it possible to capture analytically the issues with which the theoretical approach outlined in the previous section is concerned.

The next two sections present the results of the analysis of Chinese and Japanese offline and online narratives dealing with the war. To make the analysis transparent, the words referring to the questions guiding the analysis (when, where, what, who, how and why) have been inserted in brackets into the text, and the lessons that the narratives end with are highlighted.

\section{Chinese and Japanese offline war narratives}

Museums are arguably one of the most important traditional technologies of memory. The author has visited and collected material at about 20 Chinese and more than 30 Japanese museums dealing with the war and analysed much of this material in detail. ${ }^{68}$ However, due to space restrictions, this section can only briefly recapitulate the analysis of the most prominent narratives about the war between Japan and China as depicted in the museum exhibitions at the Chinese People's War of Resistance Museum, the Yüshükan in Tokyo and the Hiroshima Peace Memorial Museum. These are all prominent museums that illustrate the main themes that appear in influential Chinese and Japanese museum exhibitions concerned with the war. Because Japan's collective memory landscape is more diverse than China's, two Japanese museums which exemplify the two most prominent types of Japanese narratives are analysed.

The scene of the narrative at the Chinese People's War of Resistance Museum on the outskirts of Beijing is mainly the Chinese battlefield [where] during the war. While a few references are made to developments in Sino-Japanese relations from the normalisation of bilateral relations in 1972 onwards, the story more or less ends in 1945 [when].

The main act focused on is the war. The Japanese military is described as waging a war of aggression [what] against China, while the Chinese agents fight a War of Resistance and an Anti-Fascist War [what]. Apart from these overarching acts, more specific events include atrocities [what] 'wantonly' and 'cruelly' [how] perpetrated by Japanese troops [who] against the Chinese people. Apart from textual material, exhibits 
negatively portraying Japanese agents include instruments used to torture the Chinese. The Chinese Communist Party (CCP) is cast as the main actor [who]. The collective grouping of the 'Chinese people' also appears as a prominent actor, but it benefits from the crucial leadership of the CCP. The CCP is depicted as having played a pivotal role by uniting the people in resistance at a time when the nation's very existence was in imminent danger. While the purpose behind the acts carried out by the CCP is thus clearly to save the nation from extinction [why], the narrative is less clear concerning why the Japanese aggressors acted in the way that they did. The main agents appearing in the narrative are labelled in ways that stress nationality [who]. In this way, a narrative is constructed about national struggle by positively depicted Chinese heroes against negatively portrayed invading foreign aggressors.

After much of the narrative has stressed the role of the CCP as saviour of the nation during the war, the exhibition ends with an explicit lesson emphasising the importance of national unity and of supporting the CCP and its policies in the present. Just as the Chinese people's war effort, led by the CCP, is portrayed as a great contribution to the world, Chinese development, under the CCP's leadership, is described as part of a 'solemn mission' that will become another great contribution to the world. The 'solemn mission' is also said to include the 'unification of the motherland', alluding to the longhoped-for reunification with Taiwan. This unification, it appears, is only possible if all Chinese people support the CCP's policies.

The Yüshükan war museum in Tokyo, which is operated by the controversial Yasukuni Shrine - known for its enshrinement of Japan's war dead, including Class A war criminals - offers the most striking example of a Japanese nationalist collective memory narrative.

The scene stretches over a long time period as all of Japan's wars since the nineteenth century are covered, even though the most recent one is given the most space. Western colonialism in Asia [where] forms part of the background. Compared with the Chinese narrative, the Yüshükan's story covers events that occurred after 1945 [when] to a much greater extent. Most strikingly, it constructs a causal link between Japan's war effort and post-war decolonisation:

It was after the Japanese military's battles that overthrew colonial authorities during the Greater East Asian War that the independence of Asian nations was realised. The flame that once flared under the Japanese military's occupation did not fade out when Japan was defeated and through independence wars nation states were born one after another.

The narrative emphasises national identity. The most meaningful acts carried out by the main actors, that is, Japanese soldiers [who], involve heroically [how] sacrificing their lives [what] for the country [why]. These heroic deeds are interpreted as having laid the foundations for Japan's post-war prosperity. Japanese military actors are also described as carrying out actions commonly associated with war such as advancing, attacking and capturing various areas [what]. Chinese military actors [who] perform similar actions but are more often ascribed responsibility for unprovoked attacks on Japanese troops and civilians. Most events are described as normal military operations and words such as 'massacre' and 'murder' are rarely used. The Japanese military's 
actions are hence given an air of necessity and the war is portrayed not as a war of aggression but as an ordinary war, which arguably makes it possible to depict Japanese actors positively and stress heroic sacrifice.

The lessons involve telling Japanese visitors that they should be grateful to, and can learn precious things from, the heroes who ostensibly sacrificed themselves for the nation. It is implicitly suggested that the lesson to be learnt is that Japanese people living today should also be willing to make sacrifices for the nation.

At the Hiroshima Peace Memorial Museum, the scene is to a large extent local with detailed description of the damage done by the bomb in Hiroshima [where]. Wartime developments are covered to some extent but mainly provide context to the nuclear bombing [what]. The narrative, however, also contains a large global [where] component on the post-war period, labelled the nuclear age [when].

In contrast to the other two exhibitions, national identity is not emphasised. Instead, many participants are described as citizens of Hiroshima or labelled using their names. In addition, the relationship between humans and the atomic bomb is a key component of the narrative, meaning that, to some extent, the category of humanity is stressed [who].

Throughout the narrative, the human agency is downplayed, not only in the relatively limited descriptions of Japanese aggression in China, but also when it comes to American agency. American agency is clear in the account of the development of the bomb and the choice to use it against Japan. It is stated that the bomb was used to justify the costs of developing it and to 'prevent the Soviet Union from extending its sphere of influence' [why]. However, agency is downplayed in the actual act of dropping the bomb [who]. Instead, people are victimised by the bomb itself [who]. Through this obfuscation of agency history is portrayed as something that happens rather than something that is made [who, how]. Consequently, responsibility for the war is obscured [why].

The historical lesson is explicit: the damage caused by the bomb was 'so terrible that a way of thinking took root in people, according to which humans cannot coexist with nuclear weapons'. Therefore, nuclear weapons must be abolished. The anti-nuclear peace message alludes to Japanese policies such as the Three Non-nuclear Principles according to which Japan cannot possess, manufacture or harbour nuclear weapons, as well as Article Nine of the Japanese constitution, which states that 'the Japanese people forever renounce war as a sovereign right of the nation and the threat or use of force as means of settling international disputes'. The museum's message is thus closely related to current debates over Japanese security policy.

Overall, this analysis corroborates some of the findings of existing research on Chinese and Japanese offline collective memory narratives. For instance, numerous studies have demonstrated that the narratives about the Second Sino-Japanese War found in Japanese and Chinese traditional technologies of memory such as history textbooks, films and museums tend to be highly selective, and certain events, episodes or themes are often focused on to such an extent that the war might even be reduced to them. In China, the Nanjing massacre and other atrocities perpetrated by the Japanese military are often taken to epitomise the war. ${ }^{69}$ In Japan, in contrast, the atomic bombings and other hardships suffered by Japanese civilians tend to be highlighted while Japanese aggression is given scant attention. ${ }^{70}$ The next section explores whether online accounts narrate the war differently. 


\section{Chinese and Japanese war narratives in Wikipedia}

This section presents the results of the analysis of the Chinese and Japanese Wikipedia articles dealing with the war. Although all the articles have been analysed, due to space restrictions and the fact that the entries are very long, it is only possible to summarise the analysis of a limited number of key events and episodes. There is remarkable consistency in the portrayal of events in the articles, however, these examples are nonetheless representative of the complete narratives. Overall, the Japanese and Chinese Wikipedia entries are quite comprehensive and cover roughly the same episodes, even though some are labelled differently. ${ }^{71}$

\section{The background to the war}

Both language versions describe the scene by tracing the background to the war to the nineteenth century, a setting they depict as heavily influenced by imperialism [when]. Yet, they do so in starkly different ways. The Chinese version largely focuses on Japanese imperialism [what], mentioning, for example, the 1874 [when] Mudanshe incident in which Japan [who] 'invaded Taiwan' [what], the 1894-1895 [when] Sino-Japanese War (Jiawu zhanzheng), and how China's internal disputes and weaknesses led Japan and Russia to 'cast greedy eyes' on China and set out to 'invade and seize by force' China [what, how]. The Chinese version portrays the background scene as characterised by Japanese imperialism without pointing out where such imperialist ideas came from or any other factors that might have influenced Japanese actions.

The Japanese version, by contrast, describes the scene as one in which Western imperialism [who] encroached on East Asia [where] and basically 'shocked' Japan into embarking on a course that forced it to modernise, become a great power and embrace an imperialist foreign policy [why]. China [who] is contrastingly described as having failed to modernise and therefore having 'suffered aggression (shinryaku) [what] from Japan' [why]. In depicting the scene at the time as one where, in the face of Western colonialism, East Asian states could either modernise or suffer aggression [when, where], it portrays Japanese actions as considerably more understandable under the circumstances than the Chinese version does [why].

\section{The Shanghai incident/Songhu battle}

Both the Japanese and the Chinese versions describe a large number of battles. One of the most important of these is the Shanghai incident/Songhu battle, sometimes compared with the Battle of Stalingrad. ${ }^{72}$ The Japanese version of what it labels the Shanghai incident begins by mentioning that on 9 August 1937:

navy first lieutenant Ōyama Isao of the Japanese military's Shanghai Special Land War Group was shot more than 30 times by the Chinese Safety Forces [who] in the non-militarised zone in Shanghai. He was killed, his face smashed, and his body filled with holes [what].

Armed soldiers from the regular Chinese Army are said to have infiltrated the non-militarised zone in violation of the 1932 armistice agreement. Japan responded by demanding that China withdraw its troops, to which the Chinese Mayor of Shanghai replied: 'I 
am powerless and there is nothing I can do'. It is then stated that on 13 August, the Chinese Army [who] 'launched an attack [what] on the Japanese naval landing force', whereupon 'the Japanese landing force [who] began its counterstrike' [what]. The Japanese narrative not only ascribes agency and responsibility for starting hostilities to the Chinese side, but also highlights that Chinese forces killed civilians: 'the Chinese air force $[w h o]$ initiated the Shanghai bombing raid, without hitting Japanese battle ships, but instead bombing the pleasure quarters in the Shanghai concessions, killing and injuring more than 1,000 civilians, including foreigners' [what]. Chinese culpability is underscored through the inclusion of photos showing civilian victims of the Chinese military's air strikes. There is no mention of possible victims of Japanese air raids, which are said to have begun on 15 August.

While China is ascribed responsibility for starting hostilities, the narrative downplays Japanese agency and purpose, suggesting that the Japanese side merely reacted and noting that:

There is the opinion that the Japanese government and military authorities did not want the flames of war to spread but, on 15 August, the Konoe cabinet made a public declaration, saying 'we have reached the limits of our patience, and we will punish the cruelty of the Chinese Army, and we urge the Nanjing government to [express] regret (hansei)'. The war's objective was said to be the eradication of anti-Japanese movements, and harmony between the three countries of Japan, Manchuria, and China [why].

The Japanese narrative states that following these events 'all areas of China became embroiled in the full-scale Japanese-Chinese War'.

The Chinese account of this episode, which it labels the Songhu battle, begins earlier [when] than its Japanese counterpart:

In mid-July [1937], the Japanese Navy commander-in-chief in Shanghai, Hasegawa Kiyoshi [who], suggested to Tokyo that it was unsuitable to limit the battleground only to Northern China, and that (they) [who] should simultaneously storm and capture Shanghai and Nanjing [what] in order to separate the Chinese military forces, and facilitate their doom [why]. In late July, Hasegawa Kiyoshi used the disappearance of one marine corps soldier as a pretext [how] for putting troops [what] in Zhabei in Shanghai. On 9 August, Chinese and Japanese troops clashed at Shanghai airport.

The narrative then describes how, on 13 August 1937, the Chinese Army [who] 'attacked [what] full of vigour and valour [how], and the air force bombed [what] the Japanese warships'. The Chinese version thus ascribes responsibility to the Japanese side by mentioning the suggestion to attack Shanghai and Nanjing along with the use of a pretext for stationing troops in Zhabei. It also mentions that the Japanese military bombed several Chinese cities and uses photographs that portray the Japanese side negatively. The most notable photograph shows a 'Chinese baby' sitting on the railway tracks at 'Shanghai South Railway station, which suffered Japanese bombing during the Songhu battle'.

The Chinese version at times refers to the Japanese military as the 'enemy military' (dijun) [who], suggesting a Chinese rather than a neutral point of view. In addition, its 
occasional depictions of Chinese actors as heroes - describing the Chinese Army's attack as 'full of vigour and valour', for example - is hardly in line with Wikipedia's principle that entries should take a neutral point of view. The Japanese narrative avoids adopting an obviously Japanese point of view through, for instance, heroic language, but it is nonetheless far from neutral. It is clearly selective and repeatedly depicts Chinese agents negatively and ascribes responsibility to them while downplaying Japanese responsibility.

\section{The Nanjing massacre/incident}

The Japanese Army's capture of Nanjing in December 1937 is one of the most contentious bilateral episodes with regard to how the war is remembered. ${ }^{73}$ The Japanese Wikipedia version describes it in the following way:

On 13 December, the Japanese military [who] occupied Nanjing. The Nanjing incident (jiken) took place in which the Japanese Army is said to have committed mass-murder (tairyo satsugai) and rape [what] of prisoners from the GMD government's army, people from the defeated army, soldiers in ordinary clothes, and civilians. However, there is controversy concerning the incident [what].

The Chinese version narrates it quite differently:

After the Japanese soldiers [who] entered Nanjing, they plundered, raped, and massacred (tusha) [what] without restraint [how]. For a week, captured officers and soldiers, as well as common people, women, and children were collectively shot (with machine guns) or hacked to death $[w h a t]$. The Japanese military [who] used ropes, took several hundred unarmed rank-andfile soldiers or common people, tied them up and used machine guns to shoot (them) or petrol to burn (them) [what].

While the Chinese narrative is characterised by certainty in its treatment of the act and Japanese agency, the Japanese version, by saying that 'the Japanese army is said to have committed mass-murder and rape' (emphasis added) and that there is 'controversy' concerning the 'incident', sheds doubt on what happened and thereby portrays the Japanese military less negatively. While it is mentioned in both the Japanese and Chinese narratives, the treatment of the Nanjing massacre is relatively brief even in the Chinese account.

\section{The nuclear bombings and the end of the war}

The Chinese version only briefly mentions the nuclear bombings, stating that:

On 6 August 1945, in order to avoid a landing operation with heavy casualties, as well as the (possibility that) the Soviet Union would take the first steps to seize Japan proper, the US military dropped the first nuclear bomb on Hiroshima, and again on 9 August dropped the second nuclear bomb on Nagasaki.

It is then mentioned that Japan surrendered following the bombings. 
More surprisingly, given the prominence of the nuclear bombings in many other Japanese narratives about the war, the Japanese version is even briefer, only mentioning the bombings in a list of events that occurred in 1945: ' 6 August and 9 August: the USA drops nuclear bombs on Hiroshima and Nagasaki'. Both the versions thus provide very short accounts of the nuclear bombings: not only are the death tolls not provided, but there is no mention of casualties whatsoever.

Both the versions contain sections on events that took place after the war ended. The Chinese version deals in some detail with the 'post-war trials' of Chinese traitors and Japanese war criminals [why]; peace treaties; changes in territory, most notably territory returned to China from Japan; a discussion on statistics about the war; and the commemoration of the war and its effects. The Japanese version, by contrast, makes no explicit reference to the post-war trials or the fact that the Japanese people were tried and convicted of war crimes, thereby circumventing the issue of overall responsibility for [why], as well as the nature of, the war.

Importantly, unlike the museum exhibitions analysed above, the Wikipedia accounts do not present any lessons for the future. In this way, they do not seek to make sense of and propose certain policies or actions on the basis of the past in the same ways as the museum exhibitions.

\section{Conclusion}

This article has found that the Wikipedia entries on the war between China and Japan in the 1930s and 1940s differ substantially from the narratives in traditional technologies of memory, such as museums, in that they do not focus to the same extent on particular experiences or episodes. In this sense, Wikipedia shows greater conciliatory potential as it apparently fulfils the first of the two steps necessary for reconciliation, namely that the two sides remember more or less the same events and episodes. ${ }^{74}$ In addition, online narratives do not construct national identities to the same extent and do not seek to make sense of the past by presenting lessons. Wikipedia's neutral point-of-view principle, which reflects historical determinism, appears to have an impact on the narratives constructed. It therefore seems that Wikipedia can, at least to some extent, facilitate more conciliatory narratives in accordance with historical determinist propositions.

At the same time, however, even though both the Japanese and Chinese entries have existed for a long time and have been edited many times by a large number of editors, significant differences remain between them. While editing continues, in both the versions, episodes are depicted in quite consistent ways, suggesting that the narratives have become relatively settled and that in each of the two language versions what is considered a fairly neutral point of view has been achieved. The Japanese account tends to downplay Japanese agency and emphasise Chinese agency and responsibility, while the Chinese narrative does the complete opposite. Mitigating circumstances that are described as characteristic of the setting and that provide the background on why the Japanese government or military acted as they did, for example, in attacking China or committing atrocities, are given a great deal of space in the Japanese version, but are hardly ever referred to in the Chinese one. In other words, even though attempts appear to have been made in the Wikipedia accounts to describe the past from a neutral point of 
view and in accordance with historical determinist ideas, a clear bias in favour of the ingroup and against the out-group can be detected. This bias seems to be influencing what is considered a neutral point of view. Put differently, Wikipedia fails to fulfil the second step necessary for reconciliation, because episodes and occurrences are narrated in radically different and incompatible ways. ${ }^{75}$

This article concludes that despite the fact that Wikipedia's neutral point-of-view principle should facilitate more conciliatory narratives - and thereby support the historical determinist approach to collective memory - this is not the case. Although the Wikipedia narratives are more conciliatory than those found in offline memory sites, they are nonetheless fundamentally self-serving. At the same time, the article's findings also differ from instrumentalist propositions. Instrumentalism argues that powerful elites can mould collective memory according to their interests and it would therefore expect Wikipedia accounts to more or less reflect those that dominate in the offline sphere. Yet, as mentioned, the offline narratives are far less comprehensive in their coverage and considerably more explicit in how they construct meaning than the online narratives analysed in this article. Attempts appear to have been made to follow the principles promoted by Wikipedia and historical determinism. However, these attempts were ultimately unsuccessful as selfserving bias is pervasive. This article argues that such bias in favour of the in-group and against the out-group, which appears even under circumstances where norms exist that promote the construction of neutral accounts, is best understood as a form of ontological security management that protects in-group self-identity and upholds a positive view of the self. As such, it does not involve outright securitisation of collective memory or the denial of war crimes perpetrated by those seen as belonging to the in-group, but a more subtle psychological mechanism that downplays 'our' bad and 'their' good actions while emphasising 'our' good and 'their' bad actions. Such a mechanism seems to play a key role in the collective construction of the narratives analysed in this article, even though attempts are made to construct neutral accounts. These findings indicate that reconciliation is difficult to achieve even under seemingly favourable conditions. Future research should, therefore, explore how the biases that appear to function as obstacles to the construction of such narratives could be overcome, for example, through other ways of managing ontological security and maintaining a positive self-understanding.

\section{Funding}

The author(s) disclosed receipt of the following financial support for the research, authorship and/ or publication of this article: This research has been made possible through generous support from the Swedish Research Council (Grant no. 2012-5630) and the Marianne and Marcus Wallenberg Foundation (Grant no. 2016-0036).

\section{ORCID iD}

Karl Gustafsson (iD https://orcid.org/0000-0001-9897-9891

\section{Notes}

1. Jenny Edkins, 'Forget Trauma? Responses to September 11', International Relations, 16(2), 2002, pp. 243-56; Duncan Bell (ed.), Memory, Trauma and World Politics: Reflections on the 
Relationship Between the Past and Present (New York: Palgrave, 2006); Erica. Resende and Dovile. Budryte (eds), Memory and Trauma in International Relations: Theories, Cases and Debates (London: Routledge, 2013).

2. Maja Zehfuss, Wounds of Memory: The Politics of War in Germany (Cambridge: Cambridge University Press, 2007); Stephanie Lawson and Seiko Tannaka, 'War Memories and Japan's 'Normalization' as an International Actor: A Critical Analysis', European Journal of International Relations, 17(3), 2010, pp. 405-28; Matteo Dian, Contested Memories in Chinese and Japanese Foreign Policy (Cambridge, MA: Chandos Publishing, 2017).

3. Susan Dwyer, 'Reconciliation for Realists', Ethics \& International Affairs, 13(1), 1999, pp. 81-98; Karl Gustafsson, 'How to Make Former Aggressors Repent Through Shaming and Praising: The Case of Sino-Japanese Relations', Global Affairs, 1(3), 2015, pp. 315-324, DOI: 10.1080/23340460.2015.1048625.

4. For example, Sherry Turkle, Life on the Screen (New York: Simon \& Schuster, 1995); Frances Cairncross, The Death of Distance (Boston, MA: Harvard Business School Press, 1997).

5. Ekaterina Haskins, 'Between Archive and Participation: Public Memory in a Digital Age', Rhetoric Society Quarterly, 37(4), 2007, pp. 401-22; Aaron Hess, 'In Digital Remembrance: Vernacular Memory and the Rhetorical Construction of Web Memorials', Media, Culture \& Society 29(5), 2007, pp. 812-30.

6. The war is known in China as the War of Resistance against Japan (kangri zhanzheng) and in Japan as the Japan-China War (nitchū sensō).

7. Christian Pentzold, 'Fixing the Floating Gap: The Online Encyclopaedia Wikipedia as a Global Memory Place', Memory Studies, 2(2), 2009, pp. 255-72; Michela Ferron and Paolo Massa, 'Beyond the Encyclopaedia: Collective Memory in Wikipedia', Memory Studies 7(1), 2014, pp. 22-45.

8. Harry Eckstein, 'Case Study Method in Political Science', in Roger Gomm, Martyn Hammersley and Peter Foster (eds) Case Study Method (London: Sage, 2009), pp. 118-64.

9. Ayşe Zarakol, 'Ontological (In)Security and State Denial of Historical Crimes: Turkey and Japan', International Relations, 24(1), 2010, pp. 3-23; Karl Gustafsson, 'Memory Politics and Ontological Security in Sino-Japanese Relations', Asian Studies Review, 38(1), 2014, pp. 71-86; Maria Mälksoo, 'Memory Must be Defended: Beyond the Politics of Mnemonical Security', Security Dialogue, 46(3), 2015, pp. 221-37.

10. See Zarakol, 'Ontological (In)Security and State Denial of Historical Crimes'.

11. See Pierre Nora, Realms of Memory (New York: Columbia University Press, 1996).

12. For example, Jutta Haider and Olof Sundin, 'Beyond the Legacy of the Enlightenment? Online Encyclopaedias as Digital Heterotopias', First Monday, 15(1), 2010<https://firstmonday.org/ojs/index.php/fm/article/view/2744/2428>

13. Louis Kriesberg, 'Reconciliation: Aspects, Growth, and Sequences', International Journal of Peace Studies, 12(1), 2007, p. 2.

14. David A. Crocker, 'Reckoning With Past Wrongs: A Normative Framework', Ethics \& International Affairs, 13(1), 1999, pp. 60-61; cf. Yinan He, The Search for Reconciliation: Sino-Japanese and German-Polish Relations Since World War II (Cambridge: Cambridge University Press, 2009), pp. 18-20; Anne Rigney, 'Reconciliation and Remembering: (How) Does it Work?', Memory Studies, 5(3), 2012, pp. 251-58.

15. Yehudith Auerbach, 'The Reconciliation Pyramid: A Narrative-based Framework for Analysing Identity Conflicts', Political Psychology 30(2), 2009, pp. 291-318; Nadim Khoury, 'Plotting Stories After War: Towards a Methodology for Negotiating Identity', European Journal of International Relations, 24(2), 2018, pp. 367-90.

16. James Bohman, 'Expanding Dialogue: The Internet, the Public Sphere and Prospects for Transnational Democracy', Sociological Review, 51(1), 2004, pp. 131-55; Nancy Fraser, 
'Transnationalizing the Public Sphere: On the Legitimacy of Public Opinion in a PostWestphalian World', Theory, Culture and Society, 24(4), 2007, pp. 7-30.

17. For example, Turkle, Life on the Screen; Cairncross, The Death of Distance.

18. Cairncross, The Death of Distance, p. xvi.

19. Evgeny Morozov, The Net Delusion (London: Allen Lane, 2011).

20. Haskins, 'Between Archive and Participation'; Hess, 'In Digital Remembrance'.

21. Pentzold, 'Fixing the Floating Gap'; see also Ferron and Massa, 'Beyond the Encyclopaedia'; Karl Gustafsson, 'Chinese Collective Memory on the Internet: Remembering the Great Famine in Online Encyclopaedias', Memory Studies, 12(2), 2019, pp. 184-197, DOI: 10.1177/ 1750698017714836.

22. Maurice Halbwachs, On Collective Memory (Chicago, IL: The University of Chicago Press, 1992).

23. Jan Assmann, 'Communicative and Cultural Memory', in Astrid Erll and Ansgar Nünning (eds), Cultural Memory Studies (Berlin: De Gruyter, 2008), pp. 109-18.

24. Nora, Realms of Memory.

25. Jan Vansina, Oral Tradition as History (Madison, WI: University of Wisconsin Press, 1985).

26. Halbwachs, On Collective Memory, p. 40.

27. Assmann, 'Communicative and Cultural Memory', p. 110.

28. Assmann, 'Communicative and Cultural Memory', p. 111.

29. Vansina, Oral Tradition as History.

30. Assmann, 'Communicative and Cultural Memory', p. 113.

31. Nora, Realms of Memory.

32. Pentzold, 'Fixing the Floating Gap', pp. 262-64.

33. Pentzold, 'Fixing the Floating Gap'.

34. Pentzold, 'Fixing the Floating Gap', p. 261; Richard Rogers, Digital Methods (Cambridge, MA: The MIT Press, 2013).

35. James Curran, 'Reinterpreting the Internet', in James Curran, Natalie Fenton and Des Freedman (eds), Misunderstanding the Internet (London: Routledge, 2012), p. 14.

36. Rogers, Digital Methods, p. 31.

37. Pentzold, 'Fixing the Floating Gap', p. 260.

38. Dirk Lewandowski and Ulrike Spree, 'Ranking of Wikipedia Articles in Search Engine Revisited: Fair Ranking for Reasonable Quality?', Journal of the American Society for Information Science and Technology, 62(1), 2011, pp. 117-32; Rogers, Digital Methods, ch. 8 .

39. Alexa, 'The Top 500 Sites on the Web', <https://www.alexa.com/topsites $>$ (accessed January 2018)

40. Cindy Royal and Deepina Kapila, 'What's on Wikipedia, and What's Not ...?', Social Science Computer Review, 27(1), 2009, p. 138.

41. He, The Search for Reconciliation.

42. Shin Kawashima, 'The Three Phases of Japan-China Joint-history Research: What was the Challenge?', Asian Perspective, 34(4), 2010, pp. 19-43.

43. Ferron and Massa, 'Beyond the Encyclopaedia', p. 25; cf. Pentzold, 'Fixing the Floating Gap', p. 264.

44. Wikipedia, 'Wikipedia: Neutral Point of View', <https://en.wikipedia.org/wiki/ Wikipedia:Neutral_point_of_view> (accessed September 2017).

45. Jimmy Wales, cited in Rogers, Digital Methods, p. 167.

46. Wikipedia, 'Wikipedia: Consensus', <https://en.wikipedia.org/wiki/Wikipedia:Consensus > (accessed September 2017); Rogers, Digital Methods, p. 166. 
47. Eckstein, 'Case Study Method in Political Science'.

48. Rogers, Digital Methods, pp. 165-67.

49. Number of edits as of 3 July 2017, when the versions analysed were retrieved: Chinese version, created 10 October 2003, 5264 edits; Japanese version, created 15 April 2003, 1450 edits. The Chinese version analysed is available at $<$ https://zh.wikipedia.org/w/index.php?title= 中国抗日战争\&oldid=45028934 >; the Japanese version analysed is available at $<$ https:// ja.wikipedia.org/w/index.php?title=日中戦争 \&oldid=64484127 $>$. It should be noted that we cannot know the nationality of all editors of Wikipedia entries for certain. There are indications that many editors of Chinese Wikipedia are located outside mainland China, for example, in Hong Kong and Taiwan (see, for example, Gustafsson, 'Chinese Collective Memory on the Internet'). However, both Hong Kong and Taiwan also suffered from Japanese aggression.

50. Elazar Barkan, The Guilt of Nations: Restitution and Negotiating Historical Injustices (Baltimore, MD: Johns Hopkins University Press, 2000), pp. xxi-xxii; Berger, War, Guilt, and World Politics After World War II (Cambridge: Cambridge University Press, 2012) pp. 14-18; Dian, Contested Memories, pp. 8-10.

51. For example, John Paul Lederach, Building Peace: Sustainable Reconciliation in Divided Societies (Washington, DC: United States Institute for Peace, 1997); Ruth G. Teitel, Transitional Justice (New York: Oxford University Press, 2000); Berger, War, Guilt, and World Politics, pp. 18-19; Dian, Contested Memories, pp. 8-10.

52. Berger, War, Guilt, and World Politics, p. 14; Dian, Contested Memories, p. 10.

53. For example, Elazar Barkan, 'Introduction: Historians and Historical Reconciliation', The American Historical Review, 114(4), 2009, pp. 899-913; Kamila Szczepanska, 'Towards a "Common" View of Difficult Past? The Representation of Atomic Bombings in Trilateral Teaching Materials', Journal of Peace Education, 14(1), 2017, pp. 114-29.

54. Ronald Grigor Suny, 'Truth in Telling: Reconciling Realities in the Genocide of the Ottoman Armenians', The American Historical Review, 114(4), 2009, p. 930-46.

55. Eric Hobsbawm and Terrence Ranger, The Invention of Tradition (Cambridge: Cambridge University Press, 1983); Yael Zerubavel, Recovered Roots: Collective Memory and the Making of Israeli National Tradition (Chicago, IL: The University of Chicago Press, 1995), He, The Search for Reconciliation; Berger, War, Guilt, and World Politics, pp. 19-23; Dian, Contested Memories, pp. 5-8; Giulio Pugliese and Aurelio Insisa, Sino-Japanese Power Politics: Might, Money and Minds (London: Palgrave Macmillan, 2017).

56. R.D. Laing, The Divided Self (London: Penguin, 1959); Anthony Giddens, Modernity and Self-Identity: Self and Society in the Late Modern Age (Cambridge: Polity Press, 1991).

57. Catarina Kinnvall, 'Globalization and Religious Nationalism: Self, Identity and the Search for Ontological Security’, Political Psychology, 25(4), 2004, pp. 741-67; Jennifer Mitzen, 'Ontological Security in World Politics: State Identity and the Security Dilemma', European Journal of International Relations, 12(3), 2006, pp. 341-70; Brent J. Steele, Ontological Security in International Relations: Self-Identity and the IR State (New York: Routledge, 2008).

58. Zarakol, 'Ontological (In)Security and State Denial of Historical Crimes'; Gustafsson, 'Memory Politics and Ontological Security'; Mälksoo, 'Memory Must be Defended'; Maria Mälksoo, 'The Transitional Justice and Foreign Policy Nexus: The Inefficient Causation of State Ontological Security Seeking', International Studies Review, Epub ahead of print 2 April 2018, DOI: 10.1093/isr/viy006; Bahar Rumelili, 'Breaking With Europe's Pasts: Memory, Reconciliation, and Ontological (In)Security', European Security, 27(3), 2018, pp. 280-95; Karl Gustafsson, 'Temporal Othering, De-Securitisation and Apologies: Understanding 
Japanese Security Policy Change', Journal of International Relations and Development, 2019, Epub ahead of print 3 January, DOI: 10.1057/s41268-018-00168-y.

59. Fritz Heider, The Psychology of Interpersonal Relations (Hillsdale, NJ: Lawrence Erlbaum, 1958).

60. Sandra Schruijer, Mathias Blanz, Amélie Mummendey, Jim Tedeschi, Beata Banfai, Helga Dittmar, Petra Klaubaumhüter, Abdelwahab Mahjoub, Joanna Mandrosz-Wroblewska, Luisa Molinari and Xavier Petillon, 'The Group-Serving Bias in Evaluating and Explaining Harmful Behaviour', The Journal of Social Psychology, 134(1), 1994, p. 47-53.

61. Miles Hewstone and Joseph M.F. Jaspars 'Social Dimensions of Attribution', in Henri Tajfel (ed.) The Social Dimension. (Cambridge: Cambridge University Press, 1984), pp. 379-404; Sandra G.L. Schruijer and Lex Lemmers (1996) 'Explanations and Evaluations by Turks and Dutchmen of Norm Violating Ingroup and Outgroup Behaviour', Journal of Community and Applied Social Psychology, 6(2), 1996, pp. 101-07.

62. Dmitry Chernobrov, 'Ontological Security and Public (Mis)Recognition of International Crises: Uncertainty, Political Imagining, and the Self', Political Psychology, 37(5), 2016, pp. 581-96.

63. See Dwyer, 'Reconciliation for Realists', p. 89.

64. Arthur Asa Berger, Narratives in Popular Culture, Media and Everyday Life (Thousand Oaks, CA: SAGE, 1997), p. 4.

65. Jane Elliott, Using Narrative in Social Research: Qualitative and Quantitative Approaches (London: SAGE, 2009), pp. 7-12.

66. Kenneth Burke, A Grammar of Motives (New York: Prentice-Hall, 1945), p. xv.

67. Michael D. Jones and Mark K. McBeth, 'A Narrative Policy Framework: Clear Enough to be Wrong?', Policy Studies Journal, 38(2), 2010, pp. 329-53.

68. Karl Gustafsson, 'Narratives and Bilateral Relations: Rethinking the 'History Issue' in SinoJapanese Relations' (Doctoral dissertation, Stockholm University, Stockholm, 2011).

69. For example, Daqing Yang, 'The Malleable and the Contested: The Nanjing Massacre in Postwar China and Japan', in T. Fujitani, Geoffrey M. White and Lisa Yoneyama (eds), Perilous Memories: The Asia-Pacific War(s) (Durham, NC: Duke University Press, 2001), pp. 50-86; Takashi Yoshida, The Making of the 'Rape of Nanking': History and Memory in Japan, China, and the United States (Oxford: Oxford University Press, 2006), ch. 11; William A. Callahan, China: The Pessoptimist Nation (Oxford: Oxford University Press, 2010).

70. For example, Laura Hein and Mark Selden, 'Commemoration and Silence: Fifty Years of Remembering the Bomb in America and Japan', in Laura Hein and Mark Selden (eds) Living With the Bomb: American and Japanese Cultural Conflicts in the Nuclear Age (Armonk, NY: M.E. Sharpe, 1997), p. 12; Berger, War, Guilt, and World Politics, p. 151; John W. Dower, Ways of Forgetting, Ways of Remembering: Japan in the Modern World (New York: The New Press, 2014), p. 144.

71. The Chinese version analysed is available at $<$ https://zh.wikipedia.org/w/index.php?title $=$ 中国抗日战争\&oldid=45028934 > ; the Japanese version analysed is available at $<\mathrm{https} / /$ ja.wikipedia.org/w/index.php?title=日中戦争\&oldid=64484127>.

72. Peter Harmsen, Shanghai 1937: Stalingrad on the Yangtze (Haverton, PA: Casemate Publishers, 2013).

73. For example, Yoshida, The Making of the 'Rape of Nanking'; Florian Schneider, China's Digital Nationalism (Oxford: Oxford University Press, 2018), Ch. 5.

74. Dwyer, 'Reconciliation for Realists'.

75. Dwyer, 'Reconciliation for Realists'. 


\section{Author biography}

Karl Gustafsson is Associate Professor at Stockholm University and Senior Research Fellow at the Swedish Institute of International Affairs. His research interests include collective memory, security and power in International Relations. His article 'Memory politics and ontological security in SinoJapanese relations' won the Wang Gungwu prize for best article published in the Asian Studies Review in 2014. He has recently published journal articles in Cambridge Review of International Affairs, Journal of International Relations and Development, Survival, European Political Science, Memory Studies, Review of International Studies and Cooperation and Conflict. 